\title{
Foam glass processing using a polishing glass powder residue
}

\author{
Yiğit Attila ${ }^{\mathrm{a}}$, Mustafa Güden ${ }^{\mathrm{b}, *}$, Alper Taşdemirci ${ }^{\mathrm{b}}$ \\ ${ }^{a}$ Department of Materials Science and Engineering, Izmir Institute of Technology, Gülbahçe Köyü, Urla, Izmir, Turkey \\ ${ }^{\mathrm{b}}$ Department of Mechanical Engineering, Izmir Institute of Technology, Gülbahçe Köyü, Urla, Izmir, Turkey
}

Received 8 November 2012; received in revised form 20 December 2012; accepted 20 December 2012

Available online 11 January 2013

\begin{abstract}
The foaming behavior of a powder residue/waste of a soda-lime window glass polishing facility was investigated at the temperatures between 700 and $950{ }^{\circ} \mathrm{C}$. The results showed that the foaming of the glass powder started at a characteristic temperature between 670 and $680{ }^{\circ} \mathrm{C}$. The maximum volume expansions of the glass powder and the density of the foams varied between $600 \%$ and $750 \%$ and 0.206 and $0.378 \mathrm{~g} \mathrm{~cm}^{-3}$, respectively. The expansion of the studied glass powder residue resulted from the decomposition of the organic compounds on the surfaces of the glass powder particles, derived from an oil-based coolant used in the polishing. The collapse stress of the foams ranged between $\sim 1$ and $4 \mathrm{MPa}$ and the thermal conductivity between 0.048 and $0.079 \mathrm{~W} \mathrm{~K}^{-1} \mathrm{~m}^{-1}$. Both the collapse stress and thermal conductivity increased with increasing the foam density. The foams showed the characteristics of the compression deformation of the open cell brittle foams, which was attributed to the relatively thick cell edges.
\end{abstract}

(c) 2013 Elsevier Ltd and Techna Group S.r.l. All rights reserved.

Keywords: A. Sintering; C. Mechanical properties; C. Thermal properties; D. Glass

\section{Introduction}

Light-weight foam glass parts have been known since 1930s [1]. Nevertheless, the interests in these materials resume nowadays [2]. Foam glass parts are inert, incombustible and relatively strong, and typically used as the thermal insulation material. However, the application areas have the potentials for widening, including light weight filler for the restoration of failed slopes, subgrade improvement material, light-weight aggregate material in concrete and water folding material for greening [3]. In the current foam glass manufacturing processes, a mixture of glass powder and blowing agent, either in the form of loose powder or briquettes, is heated above the softening $/ \mathrm{melt}$ ing point of glass. Then, the blowing agent decomposes or reacts with glass and releases gaseous products, which drive the expansion of the glass. Blowing agents are classified as neutralizers (e.g. $\mathrm{CaCO}_{3}$ and $\mathrm{CaMg}\left(\mathrm{CO}_{3}\right)_{2}$ ) and redox agents (e.g. $\mathrm{C}, \mathrm{SiC}$ and $\mathrm{Si}_{3} \mathrm{~N}_{4}$ ) [4]. Neutralizers decompose upon heating, releasing the gaseous product of

\footnotetext{
*Corresponding author. Tel.: +90 232 7506779; fax: +90 2327506701.

E-mail address: mustafaguden@iyte.edu.tr (M. Güden).
}

$\mathrm{CO}_{2}$, while redox agents react with glass, forming the gaseous products of $\mathrm{CO}_{2}, \mathrm{CO}$ or $\mathrm{N}_{2}$, depending on the composition of the used blowing agent. Various types of glass powders and blowing agents were previously investigated for the processing of foam glass. The glass particles polishing wastes containing $\mathrm{SiC}$ particles were used as blowing agent for foaming soda-lime glass powder [5] and the powder mixture of soda-lime glass and glass fiber [6]. The glass cullet mixed with $20 \mathrm{wt} \%$ fly ash was foamed using marble polishing plant sludge (mainly composing of calcite and dolomite) and using $\mathrm{SiC}$ as blowing agent [7]. The dismantled waste cathode ray tube glasses were foamed using $\mathrm{CaCO}_{3}, \mathrm{SiC}$ and $\mathrm{TiN}$ as blowing agents and hydrothermal hot-pressing [8-14]. Borosilicate glasses were reported to be effectively foamed using $\mathrm{SiC}$ and $\mathrm{Si}_{3} \mathrm{~N}_{4}$ over a wide range of temperatures [15]. Water and liquid hydrocarbons were further investigated as blowing agents in foam glass processing; the latter were recommended to retard the effect of combustion reaction rate [16,17].

About 0.9 million ton of waste glass is generated in EU annually [7]. The glass bottles in Japan were reported 1.98 million tons in 1998 and $74 \%$ of the container glass production was used as waste glass [3]. The cullet is 
estimated to reach about 0.5 million ton per year in UK [18]. Only 0.21 million ton of $0.67-0.77$ million ton of waste flat glass generated every year in UK are recycled, while the rest is used as landfill [19]. Another study reports that only $20 \%$ of the collected waste glass are returned to glass factories for re-melting [20]. The current waste glassbased foam glass manufacturing seems to be one of the most economical ways of recycling large quantities of waste glasses generated. In this study, the foaming behavior of a polishing glass powder residue was investigated experimentally. The powder residue is currently dumped in a land near the facility. The total amount of powder generated is estimated to be 30,000 ton per year. The expansion of the studied glass powder residue was shown to be resulted from the decomposition of the organic compounds on the surfaces of the glass powder particles derived from an oil-based coolant used in the polishing operations. The expansions of the glass powder were measured in-situ using an experimental foaming set-up. The compression mechanical behavior and thermal conductivities of the prepared foams were determined and compared with those reported in the literature.

\section{Materials and testing methods}

As-received glass powder was a residue of a soda-lime window/flat glass polishing facility, Camex (Bursa, Turkey). The polishing was accomplished with an oil-based coolant and the resultant polishing residue was damped into a field. The particle size of as-received glass powder (Fig. 1(a)) was determined using a Malvern Mastersizer 2000 particle size analyzer. The crystallographic structures of the powders and foams were determined using a Philips X'Pert Pro XRay Diffraction (XRD) device $(\mathrm{Cu}-\mathrm{K} \alpha$ radiation, $\lambda=1.54$ $\mathrm{A}^{\circ}$ and $40 \mathrm{kV}$ ). The Fourier transformation infrared (FTIR) analyses were performed using a Shimadzu 8400S FTIR spectrometer. The thermo-gravimetric analyses (TGA) were conducted in a Perkin Elmer Diamond TG/DTA. The elemental compositions of the powders and foams were determined using a Spectro IQ II X-ray fluorescence (XRF).
The scanning electron microscopy (SEM) analyses were performed in a FEI Quanta 205 FEG SEM. The density of the foams was determined by measuring the weight and dimensions of the test samples.

The foaming experiments were performed using the glass powder briquettes, $3 \mathrm{~cm}$ in diameter and $7 \mathrm{~mm}$ in thickness (Fig. 1(b)). The briquettes were prepared inside a cylindrical mold under $15 \mathrm{MPa}$. The foaming behavior of waste glass powder ( $70 \mu \mathrm{m}$ in average particle size) obtained by grinding soda-lime window glass was also investigated for comparison. An oil-based coolant (Potenza 40) was mixed with window glass powder with an amount of $10 \mathrm{wt} \%$ in order to investigate the effect of coolant on the foaming and TGA behavior of the glass powder. The schematic and the picture of the front view of foam expansion set-up are shown in Fig. 2(a) and (b), respectively. The details of the experimental set-up are given elsewhere [21]. Briefly, the foam expansion set-up consisted of a vertical tube furnace, linear expansion measurement system and foaming mold. The bottom of foaming mold ( $3 \mathrm{~cm}$ in diameter and $8 \mathrm{~cm}$ in height) was enclosed tightly and the glass powder briquette was placed at the bottom of the mold. A linear variable displacement transducer (LVDT) was connected to the steel expansion rod through a wire and two pulleys. A thermocouple directly contacted to the bottom of the briquette was used to measure the temperature of the briquette during foaming. Transducer and thermocouple data were collected using a data logger (Data Taker DT 80). In a typical expansion experiment, the weight of the expansion rod is balanced using a counter weight in order to minimize the load exerted to the expanding glass powder briquette (Fig. 2(a)). The foaming mold accompanying the glass powder briquette is inserted into the furnace by means of an elevator. After the briquette insertion into the furnace, the top expansion rod connected to LVDT is lowered until the rod bottom head touches the briquette surface. The linear expansion $(\mathrm{mm})$ is converted into volume percent expansion $\left(V_{E}(\%)\right)$ using the following equation:

$$
V_{E}(\%)=\frac{h_{f}-h_{o}}{h_{o}} \times 100
$$
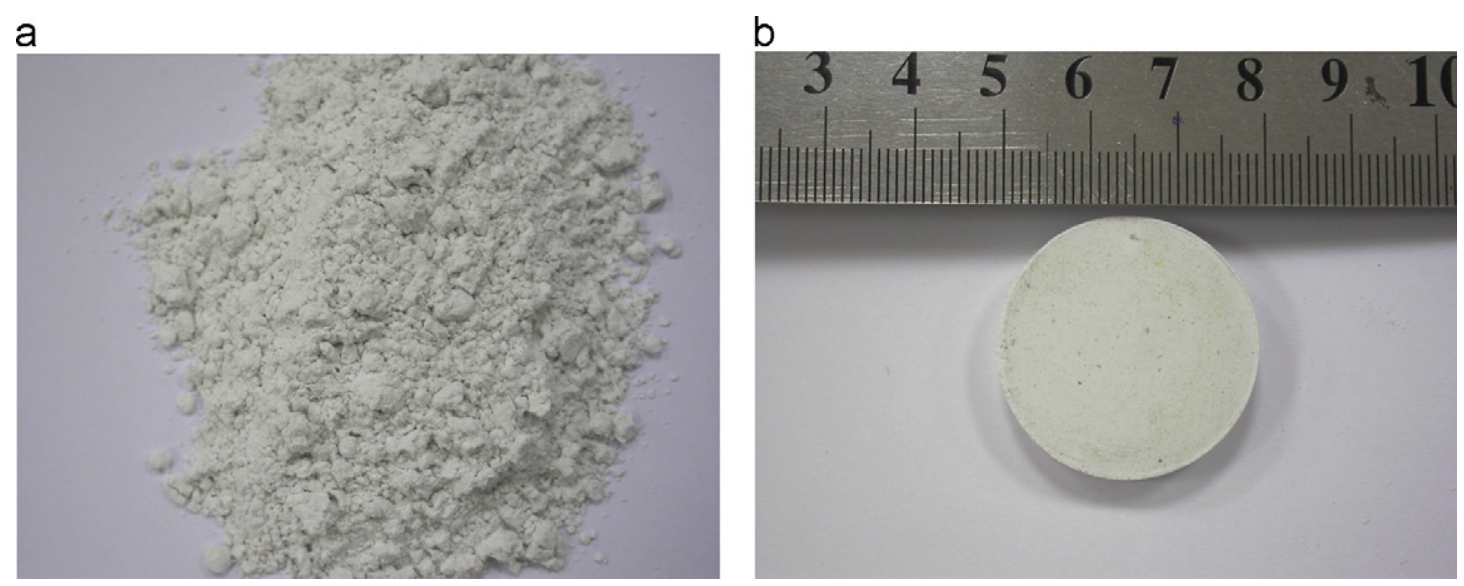

Fig. 1. The pictures of (a) as-received glass powder and (b) glass powder briquette used in the expansion experiments. 
a

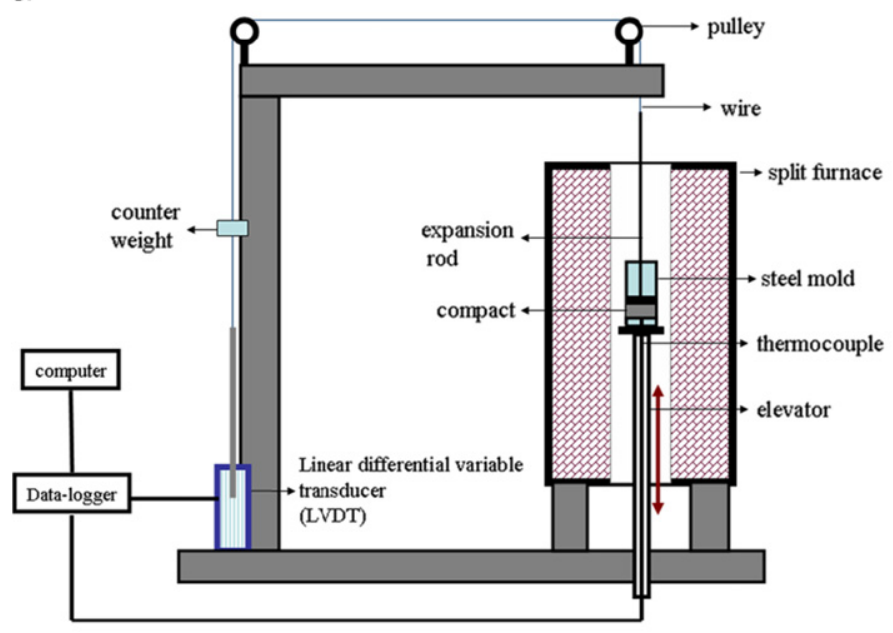

b

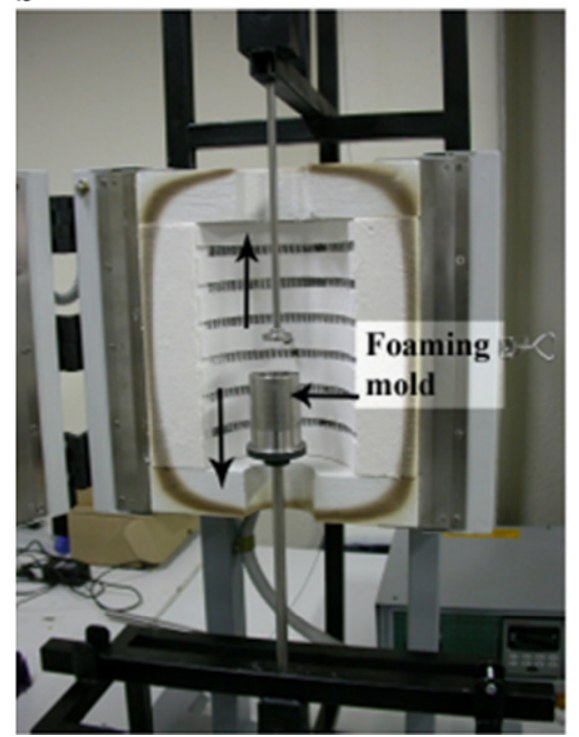

Fig. 2. (a) The schematic of foam expansion measurement set-up and (b) the picture showing foaming mold and sliding top and bottom rods.

a

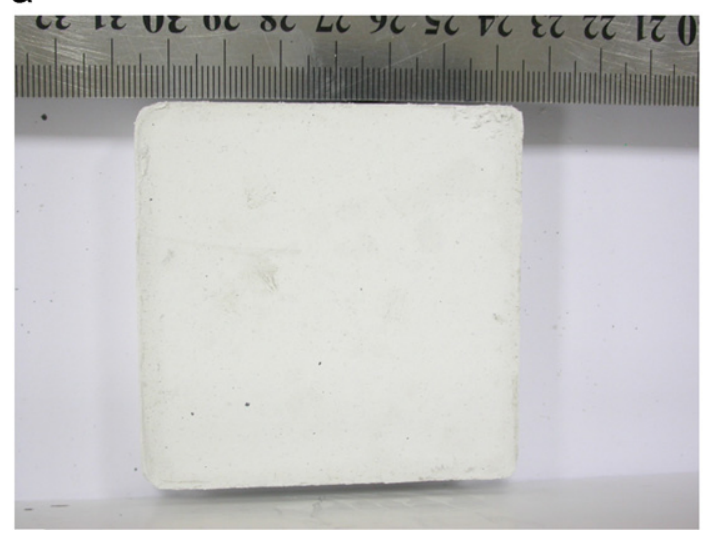

b

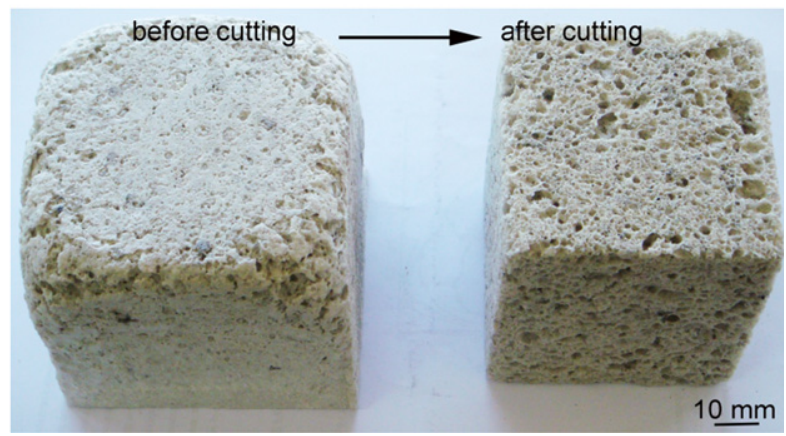

Fig. 3. (a) The pictures of glass powder used to prepare the foam samples for compression and thermal conductivity tests and (b) the pictures of the foamed glass powder briquette after foaming and cutting in the compression test sample size.

where $h_{f}$ and $h_{o}$ refer to the final and initial height of the glass powder briquette, respectively.

The foam samples for compression and thermal conductivity measurements were prepared separately by foaming $70 \times 70 \times 10 \mathrm{~mm}$ size rectangular glass powder briquettes (Fig. 3(a)). These briquettes were formed inside a steel die under $15 \mathrm{MPa}$. The powder briquette was then placed inside a steel mold. The inner surfaces of the mold were coated with a thin layer of kaolin. The kaolin layer prevented the reaction between the molten glass and the mold [12]. The expansions of the glass powder briquettes were limited to the vertical direction. The foaming was performed in a furnace between 700 and $950{ }^{\circ} \mathrm{C}\left(25^{\circ} \mathrm{C}\right.$ intervals $)$ with two heating rates: slow heating rate, $5^{\circ} \mathrm{C} \mathrm{min}^{-1}$, and relatively fast heating rate, $15^{\circ} \mathrm{C} \mathrm{min}{ }^{-1}$. After foaming, the foam samples were cut into compression and thermal conductivity test sample dimensions as seen in Fig. 3(b). The compression test samples were prepared in accord with ASTM C240-97 standard [22] with the dimensions of $50 \times 50 \times 50 \mathrm{~mm}$ (Fig. 3(b)). The quasistatic compression tests were conducted using a displacementcontrolled SHIMADZU AG-I universal tension-compression test machine at the strain rate of $2 \times 10^{-3} \mathrm{~s}^{-1}$. The thermal conductivity measurements were performed on $100 \times 50 \times 10$ $\mathrm{mm}$ size foam samples using a KEM QTM-500 thermal conductivity detector.

\section{Results and discussion}

\subsection{Characterization and expansion experiments}

The particle size of as-received glass powder ranged between $5.7 \mu \mathrm{m}\left(\mathrm{d}_{10}\right)$ and $266 \mu \mathrm{m}\left(\mathrm{d}_{90}\right)$, with an average of $22.7 \mu \mathrm{m}\left(\mathrm{d}_{50}\right)$. The composition of as-received glass powder determined by $\mathrm{X}$-ray fluorescence analysis is as following: $72.76 \% \mathrm{SiO}_{2}, 11.18 \% \mathrm{Na}_{2} \mathrm{O}, 11.31 \% \mathrm{CaO}, 1.74 \% \mathrm{MgO}$ and $1.61 \% \mathrm{Al}_{2} \mathrm{O}_{3}$. The composition of the glass cullet 
generated in various countries was reported as $67-72 \%$ $\mathrm{SiO}_{2}, 14-15 \% \mathrm{Na}_{2} \mathrm{O}, 7-11 \% \mathrm{CaO}, 1-7 \% \mathrm{MgO}$ and $1-6 \%$ $\mathrm{Al}_{2} \mathrm{O}_{3}$ [23]. Therefore, the chemical composition of the asreceived glass powder matches well with that of soda-lime window glass and the cullet (except $\mathrm{Na}_{2} \mathrm{O}$ ) collected around the world $[2,3]$.

Fig. 4 shows the TGA curves of as-received glass powder, window glass powder (control) and window glass powder mixed with $10 \mathrm{wt} \%$ oil-based coolant. The weight loss of as-received glass powder is $\sim 11 \mathrm{wt} \%$ at $662{ }^{\circ} \mathrm{C}$ and continues until about $860^{\circ} \mathrm{C}$. A weight gain, $\sim 1 \mathrm{wt} \%$, seen above $860{ }^{\circ} \mathrm{C}$ is likely due to the oxidation reactions of molten glass. Somewhat, a similar behavior is seen in the TGA curve of window glass powder mixed with $10 \mathrm{wt} \%$ oil-based coolant. The weight loss continues until about $860{ }^{\circ} \mathrm{C}$, while the weight loss at $662{ }^{\circ} \mathrm{C}$ is slightly lower, $9 \mathrm{wt} \%$. But, the weight loss of window glass powder is only about $0.5 \mathrm{wt} \%$ until $860{ }^{\circ} \mathrm{C}$ as shown in Fig. 4. The weight loss of as-received glass powder residue is, therefore, attributed to the burning of organic compounds on the glass powder particle surfaces. The weight losses of the glass powder briquettes after the foaming between 750 and $950{ }^{\circ} \mathrm{C}$ were also measured for comparison and found to be very similar to that of TGA, $11 \mathrm{wt} \%$ on the average. The XRD spectrum of the as-received powder at room temperature showed typical soda-lime window glass amorphous structure [1], while quartz, wollastonite and diopsite crystal phases of soda lime glass were detected in the XRD spectra of foam glass samples foamed above $800{ }^{\circ} \mathrm{C}$. The wollastonite and diopside are the crystal phases of the soda lime glass formed upon heating and were also previously detected in the foaming of soda lime glass powder at $950{ }^{\circ} \mathrm{C}[5,24]$ and $1000{ }^{\circ} \mathrm{C}[20]$.

Fig. 5(a) shows the volume expansion-temperature and volume expansion-time graphs of the glass powder briquettes heated to $900{ }^{\circ} \mathrm{C}$ within $3000 \mathrm{~s}(50 \mathrm{~min})$. The numbers in the same figure represent the different stages

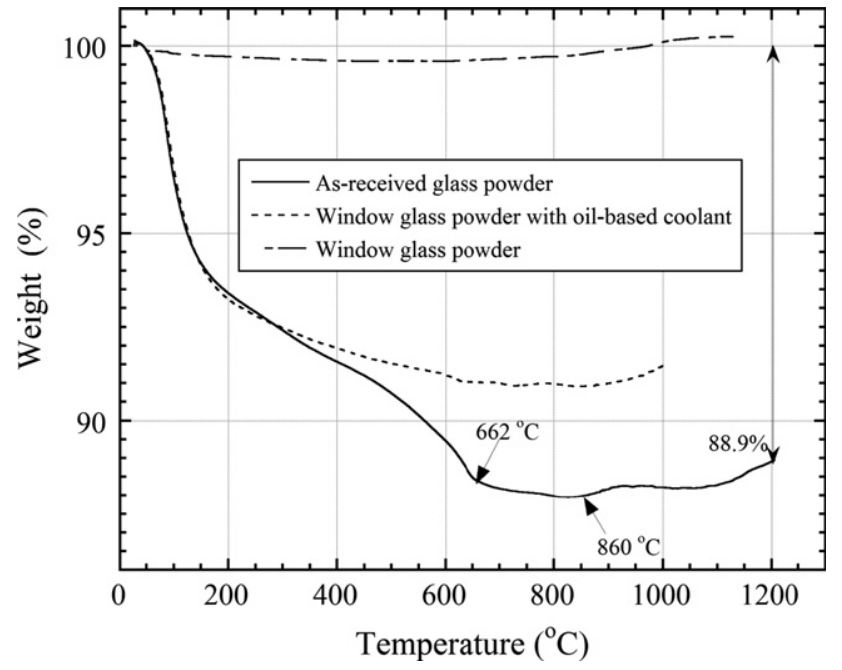

Fig. 4. The TGA curves of as-received glass powder, window glass powder and $10 \mathrm{wt} \%$ oil-based coolant mixed window glass powder.
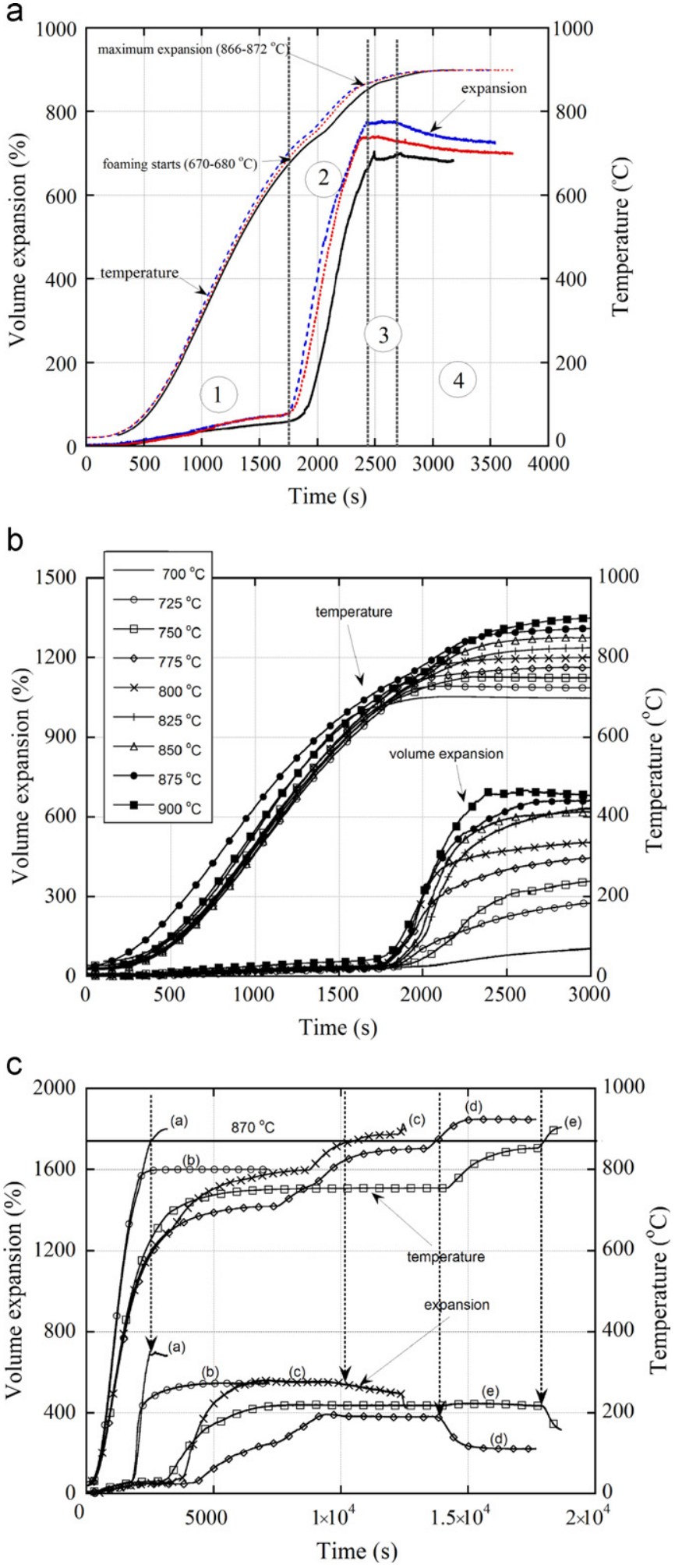

Fig. 5. The volume expansion-time and temperature-time graphs of glass powder briquettes (a) heated to the same final temperature with the same heating rate (the numbers corresponding to the different stages of the foam expansion) and heated to different final temperatures (b) with the same and (c) different heating rates.

of glass powder briquette expansion. In Region 1, the glass powder sinters as the temperature increases. A slight increase in the volume of the briquette until about $700{ }^{\circ} \mathrm{C}$ 
in this region is due to the thermal expansion of the briquette. The foaming starts and reaches the maximum expansion in Region 2 at the temperatures between 670 and $680{ }^{\circ} \mathrm{C}$ and 866 and $872{ }^{\circ} \mathrm{C}$, respectively. While, the expansion is nearly constant in Region 3 and decreases slightly in Region 4, as the temperature of the foamed glass powder briquette reaches the furnace temperature. The transition from Region 1 to Region 2 indicates the temperature at which the glass powder transforms partially or completely into a viscous liquid. However, the decomposition of the blowing agent starts before the softening of glass particles. The sintering of the particles through neck regions is believed to prevent the escape of the gases before the melting of the glass powder, causing the rapid expansion of the briquette upon the sintering and/or partial melting of the glass particles. The continued decomposition of the blowing agent at increasing temperatures further drives the expansion of the glass powder briquette. The maximum expansion is also well agreed with the TGA curve shown in Fig. 4, in which the blowing agent decomposition vanishes after about $860^{\circ} \mathrm{C}$. Therefore, no foam expansion or slightly reduced foam expansions are detected in Region 3 and Region 4. Fig. 5(b) shows the volume expansiontemperature and volume expansion-time curves of glass powder briquettes heated to the final temperatures between 700 and $900{ }^{\circ} \mathrm{C}$ with the same heating rates. The final expansions (at $3000 \mathrm{~s}$ ) are noted to increase rapidly, when the glass powder briquettes are heated up to $850{ }^{\circ} \mathrm{C}$. However, the final expansions show saturation tendency between 850 and $900{ }^{\circ} \mathrm{C}$. The final expansions are 600$750 \%$ between 850 and $900{ }^{\circ} \mathrm{C}$; the briquette thickness increases about 6 and 7 times. The selected volume expansion-time and temperature-time graphs of the powder briquettes foamed with various heating schedules (shown by letters) and different heating rates are shown in Fig. 5(c). The briquette heated quickly to $900{ }^{\circ} \mathrm{C}$ in $2500 \mathrm{~s}$ (50 min) shows the maximum expansion (a), $\sim 700 \%$, while the briquette heated quickly to $800{ }^{\circ} \mathrm{C}$ shows a lower final expansion (b), $540 \%$. The briquette heated to $800{ }^{\circ} \mathrm{C}$ with a slow heating rate (c) results in similar final expansion with the quick heating to $800{ }^{\circ} \mathrm{C}$ (b). The briquettes heated to $700{ }^{\circ} \mathrm{C}$ (d) in $8400 \mathrm{~s}(140 \mathrm{~min})$ and to $750{ }^{\circ} \mathrm{C}$ in $13,800 \mathrm{~s}$ (230 $\mathrm{min}$ ) also show comparably lower expansions. It is also noted that the expansions decrease after about $870{ }^{\circ} \mathrm{C}$, regardless of the heating schedule and rate, as shown by arrows in Fig. 5(c). The reductions in the expansions above $870{ }^{\circ} \mathrm{C}$ are partly due to the vanishing of the decomposition reactions of the blowing agent and partly due to the reduced melt viscosity leading to the collapse of the cells walls. The reduced expansions of powder briquettes at slow heating rates were also reported previously [10]. The slow heating rates cause the early release of the gases from the blowing agent, before the viscosity of the glass becomes low enough to allow the glass to expand rapidly [11].

The foam glass cellular structure evolution may be considered composing of several consecutive stages. The foaming starts in the solid state just before the melting of glass powder. The cells are initially small and spherical in shape. As the foaming proceeds, the cells not only become larger but also change the shape from sphere to polyhedral. The decaying processes become operative in the later stages as cell coarsening, cell wall rupture and drainage. The drainage decreases the thickness of cell walls, leading to thicker cell edges and cell wall rupture. The cellular structure of a foam glass is shown in Fig. 6(a). The foam sample was prepared by inserting the foaming mold into a preheated furnace $\left(800{ }^{\circ} \mathrm{C}\right)$ and holding the mold for $3000 \mathrm{~s}(50 \mathrm{~min})$ in the furnace. The foam cell walls seen in Fig. 6(a) accommodate interconnections with neighboring cells as marked by arrows. The bursting action of the gaseous products and the partial melting/sintering of the glass particles on the cell walls lead to the formation of holes between the neighboring cells, resulting in an open cell foam structure. This naturally increases the water absorption of the foamed glass. Fig. 6(b) and (c) are the SEM micrographs showing the presence of small size pores on the cell edges and cell walls. The presence of small pores on the cell edges and cell walls were also observed previously in a similar foamed glass [24]. The needle-like features seen in Fig. 6(c) on the cell walls (marked with arrows) are noted to be wollastonite and diopsite crystals. The bottom and cross-section pictures of a foamed widow glass powder $/ 10 \mathrm{wt} \%$ oil-based coolant briquette are shown in Fig. 6(d). As with foams processed using polishing glass powder residue, these foams possess open cell foam structure.

Fig. 7 shows the FTIR spectra of as-received glass powder, $10 \mathrm{wt} \%$ oil-based coolant added window glass powder and foamed glass (powdered). The FTIR spectra of glass powder and oil-based coolant added window glass powder are very similar: the peaks between 3600 and $3200 \mathrm{~cm}^{-1}$ correspond to the broad stretching of $\mathrm{O}-\mathrm{H}$ and between 2960 and $2800 \mathrm{~cm}^{-1}$ to the stretching vibration of $\mathrm{C}-\mathrm{H}$ aldehyde group. The peak at $1660 \mathrm{~cm}^{-1}$ corresponds to the stretching vibration of $\mathrm{C}-\mathrm{C}, 1460 \mathrm{~cm}^{-1}$ to the asymmetrical stretching of $\mathrm{CH}$ group and $1500 \mathrm{~cm}^{-1}$ to the aromatic structure of $\mathrm{C}=\mathrm{C}$ [25]. The above groups of bonds are absent in the FTIR spectrum of foamed glass powder. The main strong peak at $1050 \mathrm{~cm}^{-1}$ and the shoulder peak at $1200 \mathrm{~cm}^{-1}$ are the asymmetrical stretching of $\mathrm{Si}-\mathrm{O}-\mathrm{Si}$ bonds; the low frequency band between 400 and $500 \mathrm{~cm}^{-1}$ is due to the rocking motion of $\mathrm{Si}-\mathrm{O}-\mathrm{Si}$ bridges, whereas the corresponding bending mode is responsible for adsorption at $700-850 \mathrm{~cm}^{-1}$ [26]. The peaks seen between 3600 and $1500 \mathrm{~cm}^{-1}$ are due to the presence of oil-based coolant. The oil-based coolant is a neutralizing blowing agent, dissociating to give gaseous products similar to $\mathrm{CaMg}\left(\mathrm{CO}_{3}\right)_{2}$ and $\mathrm{CaCO}_{3}$, as

$\mathrm{C}_{n} \mathrm{H}_{m}+\left(\frac{m}{4}+n\right) O_{2} \rightarrow\left(\frac{m}{2}\right) \mathrm{H}_{2} \mathrm{O}+n \mathrm{CO}_{2}$

The organic compounds wetting the surfaces of the glass particles dissociate to give water vapor and carbon dioxide during heating in the furnace, leading to the expansion of the glass powder residue. 
a

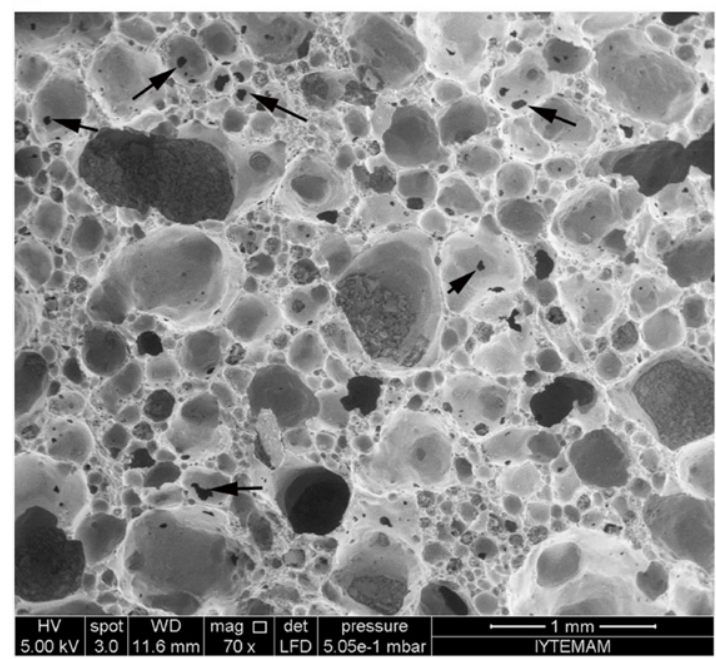

b

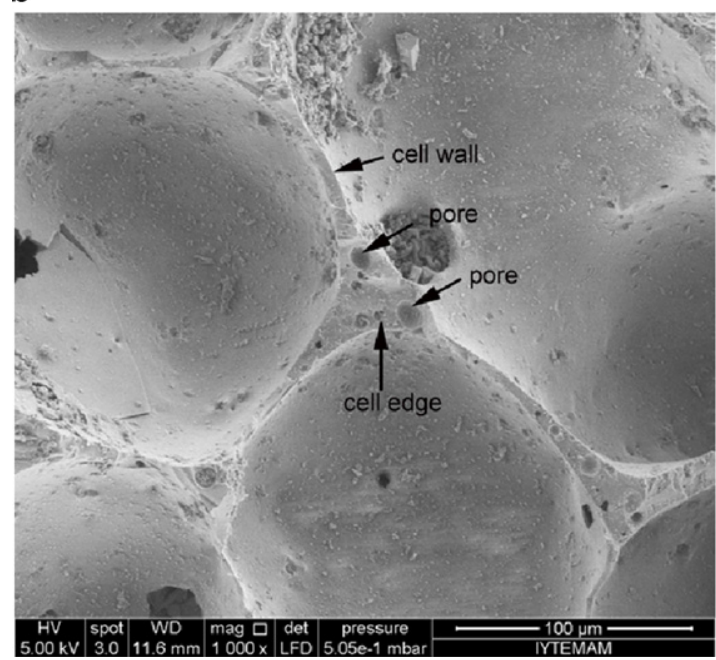

C

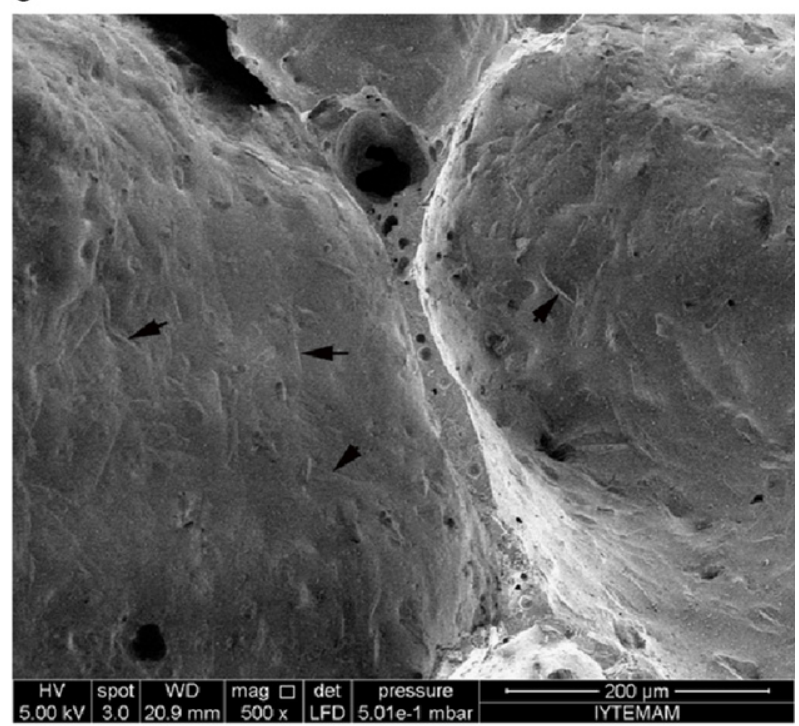

d

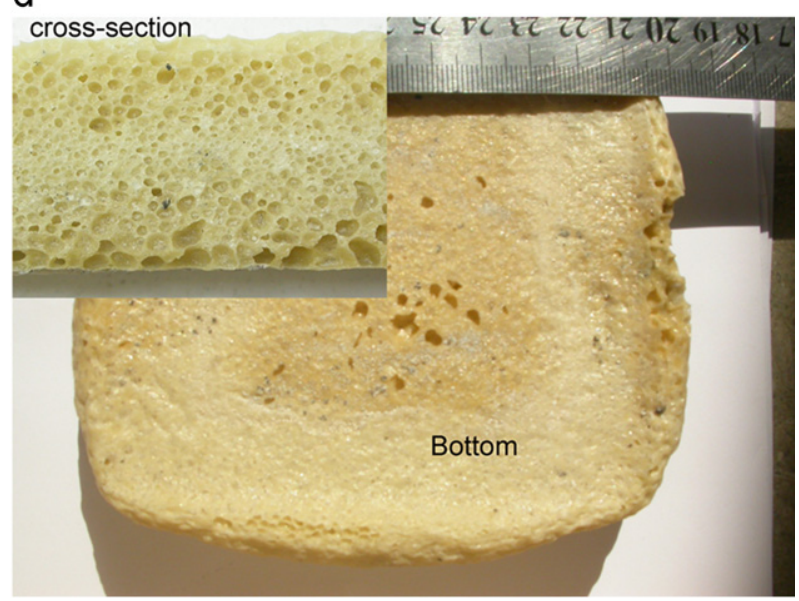

Fig. 6. The SEM micrographs of foamed glass powder $\left(800^{\circ} \mathrm{C}\right)$ showing (a) the cells, (b) small pores on the cell walls and edges, (c) wollastonite and diopsite crystals and (d) the pictures of foamed window glass powder using oil-based coolant as blowing agent.

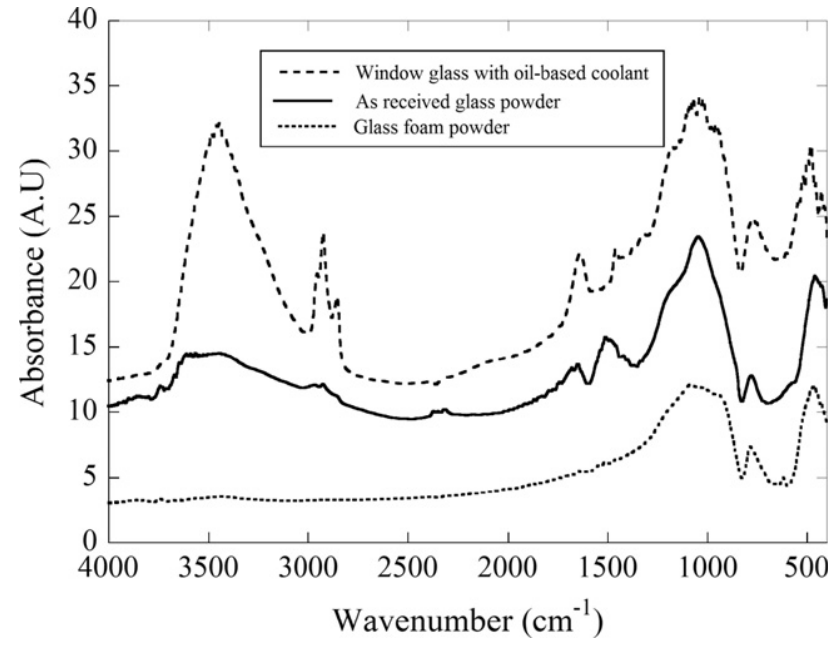

Fig. 7. The FTIR spectra of glass powder, oil-based coolant mixed window glass powder and foamed glass powder.

\subsection{Compression mechanical behavior and thermal conductivity}

The compressive stress-strain curves of the foams prepared with relatively slow $\left(5{ }^{\circ} \mathrm{C} \mathrm{min}{ }^{-1}\right)$, and fast heating $\left(15^{\circ} \mathrm{C}\right.$ $\min ^{-1}$ ) rates are shown in Fig. 8(a) and (b), respectively. The tested foam samples show the typical stress-strain behavior of the brittle foams: following the collapse stress (maximum stress) the samples fracture catastrophically. The variation of the foam collapse stresses with density is further shown Fig. 9(a). The collapse stress varies between 1 and $4 \mathrm{MPa}$ and increases with increasing foam density. No significant effect of heating rate on the collapse stresses of the foams is also seen in the same figure; therefore, the effect of heating rate is excluded in the following strength analysis. The foam collapse stress is given as [27],

$\sigma_{f}=\sigma_{\text {bend }}\left[C \phi \rho_{r e l}{ }^{3 / 2}+(1-\phi) \rho_{\text {rel }}\right]$ 
a
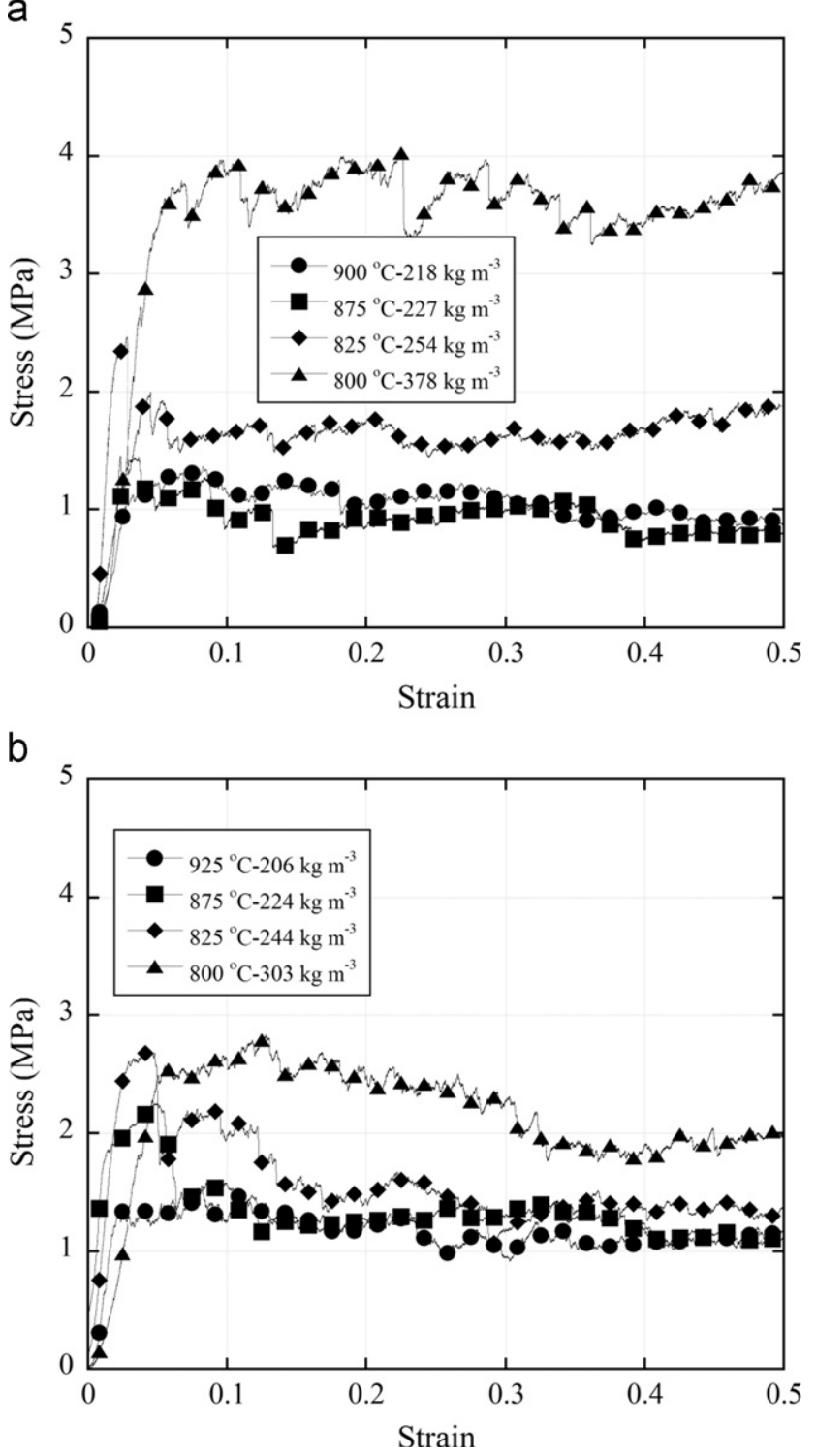

Fig. 8. The compressive stress-strain curves of foamed powder briquettes; heating rates (a) 5 and (b) $15^{\circ} \mathrm{C} \mathrm{min}^{-1}$.

where, $\sigma_{\text {bend }}$ is the bending strength of the soda lime glass; C is a constant; $\rho_{\text {rel }}$ is the relative density of the foam and $\phi$ is the volume fraction of the solids located on the cell edges. The value of $\mathrm{C}$ and the bending strength of soda lime glass are sequentially given as 0.2 [27] and $70 \mathrm{MPa}$ [5]. The first term in Eq. (3) is due to bending and the second term is due to membrane stretching of the cell walls. Eq. (3) predicts the collapse stresses of open-cell foams, when $\phi$ equals to 1 , and the collapse stresses of closed cell foams, when $\phi$ equals to 0 . The collapse stresses of the tested foam glass samples and previously investigated foam glasses are fitted with Eq. (3) using different values of $\phi$. The fitting results, collapse stress vs. density, are shown in Fig. 9(b) (references in Fig. 9(b): $1-[19], 2-[19], 3-[18], 4-[28], 5-[29], 6-[30], 7-[7]$, $8-[6], 9-[31], 10-[32], 11-[33])$. The collapse stresses of the investigated and reported foam glasses are well fitted with the $\phi$ values between 0.7 and 1 for the foam densities up to
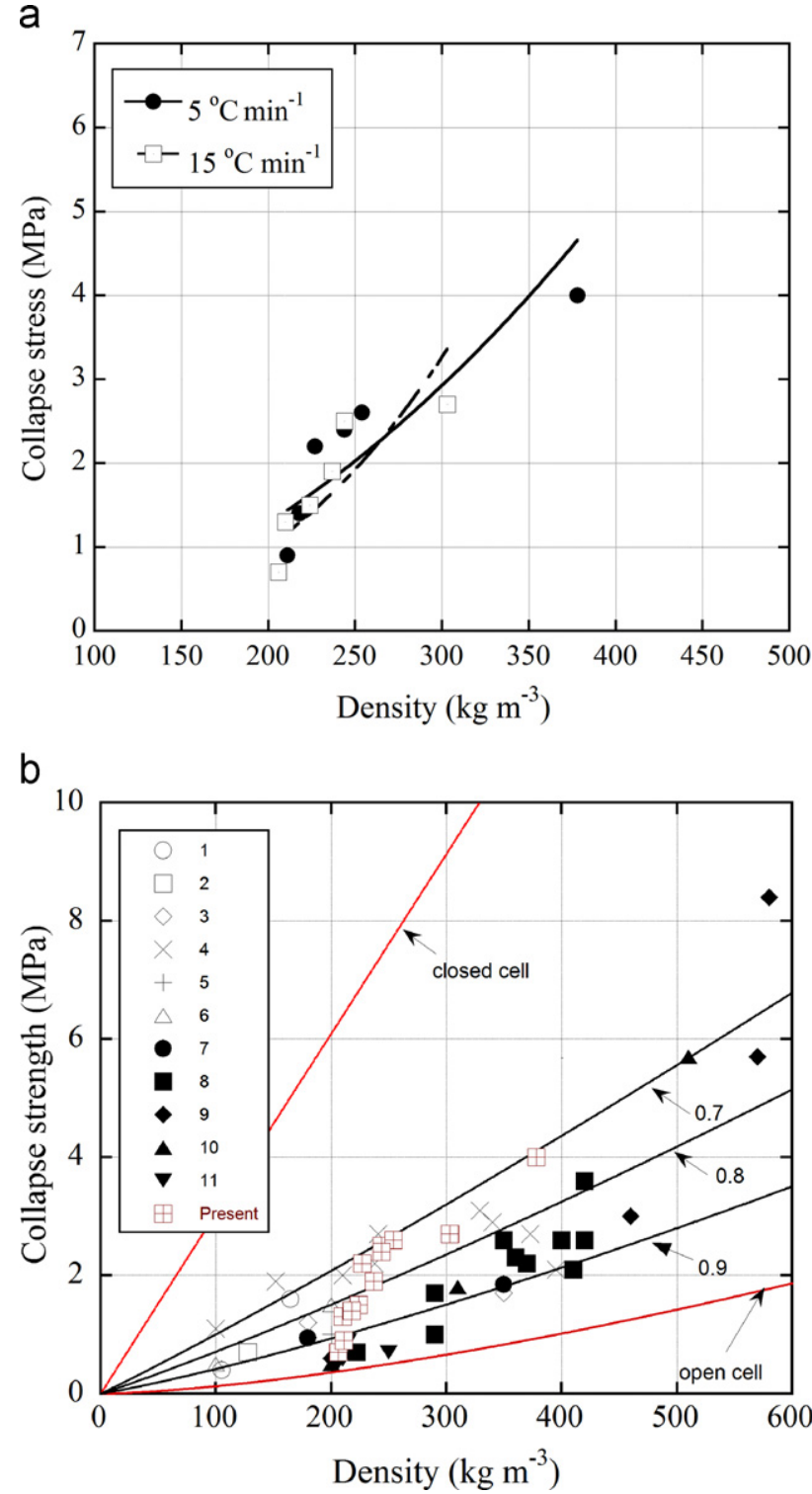

Fig. 9. (a) The variations of collapse stress with foam density and (b) the fitting results of the collapse stresses of the tested foam glass and the previously investigated foam glass with Eq. (3).

$300 \mathrm{~kg} \mathrm{~cm}^{-3}$ and with the $\phi$ values between 0.7 and 0.9 for the foam densities above $300 \mathrm{~kg} \mathrm{~cm}^{-3}$. The determined fitting values of $\phi$, in addition to the microscopic observations, confirm the open cell foam structure of the tested and previously investigated foam glasses. This is mainly caused by a high volume fraction of the solids located on the cell edges.

The thermal conductivities of the foam glass samples as function of density are shown in Fig. 10, together with the thermal conductivities of the similar foam glasses reported in the literature (references in Fig. 10: 1-[11], 2-[29], 3-[19], 4-[19], 5-[23]). Similar to the collapse stress, the thermal conductivity increases as the foam density increases. The thermal conductivities of the tested foam glass range between 0.048 and $0.079 \mathrm{~W} \mathrm{~m}^{-1} \mathrm{~K}^{-1}$. The tested foam glass samples, as noted in Fig. 10, show similar 


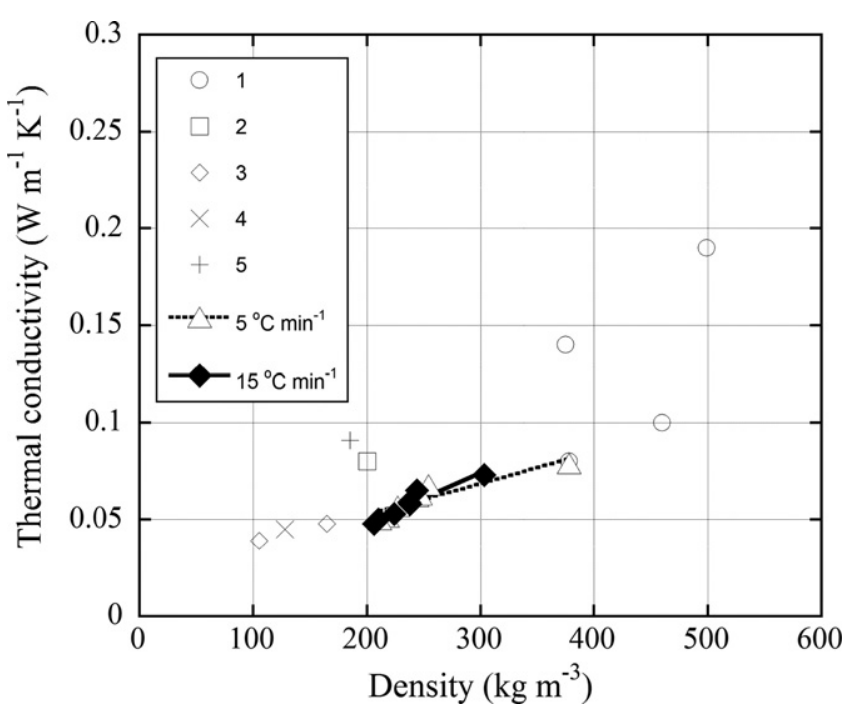

Fig. 10. The variations of thermal conductivities of the tested foam glasses and the previously investigated foam glasses with density.

thermal conductivities with the foam glasses reported in the literature: the thermal conductivities range between 0.04 and $0.05 \mathrm{~W} \mathrm{~m}^{-1} \mathrm{~K}^{-1}$ for the foam densities between 100 and $200 \mathrm{~kg} \mathrm{~m}^{-3}$.

\section{Conclusions}

The foaming behavior of a powder residue/waste of a soda-lime window glass polishing facility was investigated using an in-situ foam expansion measurement set-up at the temperatures between 700 and $950{ }^{\circ} \mathrm{C}$. The foaming was shown to start at a characteristic temperature between 670 and $680{ }^{\circ} \mathrm{C}$. The maximum volume expansions of the glass powder and the density of the foams varied between $600 \%$ and $750 \%$ and 0.206 and $0.378 \mathrm{~g} \mathrm{~cm}^{-3}$, respectively. The expansion of the studied glass powder residue was shown to be resulted from the decomposition of the organic compounds on the surfaces of the glass powder particles, derived from oil-based coolant used in the polishing. The heating rate of the foaming process had no significant effect on the collapse stress and thermal conductivity. Both the collapse stress and thermal conductivity increased with increasing the foam density and showed well agreements with those reported in the literature. The foams showed the characteristics of the deformation of the open cell brittle foams, which was attributed to the relatively thick cell edges.

\section{References}

[1] A.H. Baker, Pittsburg Corning Corp, (1938).

[2] V.A. Lotov, E.V. Krivenkova, Kinetics of formation of the porous structure in foam glass, Glass and Ceramics 59 (3-4) (2002) 89-93.

[3] J. Lu, K. Onitsuka, Construction utilization of foamed waste glass, Journal of Environmental Sciences-China 16 (2) (2004) 302-307.

[4] Y.A. Spiridonov, L.A. Orlova, Problems of foam glass production, Glass and Ceramics 60 (9-10) (2003) 313-314.
[5] E. Bernardo, R. Cedro, M. Florean, S. Hreglich, Reutilization and stabilization of wastes by the production of glass foams, Ceramics International 33 (6) (2007) 963-968.

[6] E. Bernardo, G. Scarinci, P. Bertuzzi, P. Ercole, L. Ramon, Recycling of waste glasses into partially crystallized glass foams, Journal of Porous Materials 17 (3) (2010) 359-365.

[7] H.R. Fernandes, D.U. Tulyaganov, J.M.F. Ferreira, Production and characterisation of glass ceramic foams from recycled raw materials, Advances in Applied Ceramics 108 (1) (2009) 9-13.

[8] E. Bernardo, G. Scarinci, S. Hreglich, Foam glass as a way of recycling glasses from cathode ray tubes, Glass Science and Technology 78 (1) (2005) 7-11.

[9] F. Mear, P. Yot, M. Cambon, A.M. Ribes, Elaboration and characterisation of foam glass from cathode ray tubes, Advances in Applied Ceramics 104 (3) (2005) 123-130.

[10] F. Mear, P. Yot, M. Ribes, Effects of temperature, reaction time and reducing agent content on the synthesis of macroporous foam glasses from waste funnel glasses, Materials Letters 60 (7) (2006) 929-934.

[11] F. Mear, P. Yot, R. Viennois, M. Ribes, Mechanical behaviour and thermal and electrical properties of foam glass, Ceramics International 33 (4) (2007) 543-550.

[12] H.W. Guo, Y.X. Gong, S.Y. Gao, Preparation of high strength foam glass-ceramics from waste cathode ray tube, Materials Letters 64 (8) (2010) 997-999.

[13] Z. Matamoros-Veloza, J.C. Rendon-Angeles, K. Yanagisawa, M.A. Cisneros-Guerrero, M.M. Cisneros-Guerrero, L. Aguirre, Preparation of foamed glasses from CRT TV glass by means of hydrothermal hot-pressing technique, Journal of the European Ceramic Society 28 (4) (2008) 739-745.

[14] M.J. Chen, F.S. Zhang, J.X. Zhu, Lead recovery and the feasibility of foam glass production from funnel glass of dismantled cathode ray tube through pyrovacuum process, Journal of Hazardous Materials $161(2-3)$ (2009) 1109-1113.

[15] B. Gerhard, Foaming of borosilicate glasses by chemical reactions in the temperature range $950-1150 \AA{ }^{\circ} \mathrm{C}$, Journal of Non-Crystalline Solids 38-39 (Part 2 (0)) (1980) 855-860.

[16] S.K. Goyal, I.B. Cutler, Absorption of water in waste glass as a precursor for foam formation, Journal of Non-Crystalline Solids 19 (0) (1975) 311-320.

[17] V.E. Manevich, K.Y. Subbotin, Mechanism of foam-glass formation, Glass and Ceramics 65 (5-6) (2008) 154-156.

[18] J.P. Wu, A.R. Boccaccini, P.D. Lee, M.J. Kershaw, R.D. Rawlings, Glass ceramic foams from coal ash and waste glass: production and characterisation, Advances in Applied Ceramics 105 (1) (2006) 32-39.

[19] Wrap, 〈http://www.wrap.org.uk〉, Environment Agency, Waste \& Resources Action Programme, 2011.

[20] K.K. Éidukyavichus, V.R. Matseikene, V.V. Balkyavichus, A.A. Shpokauskas, A.A. Laukaitis, L.Y. Kunskaite, Use of cullet of different chemical compositions in foam glass production, Glass and Ceramics 61 (3) (2004) 77-80.

[21] M. Guden, S. Yuksel, SiC-particulate aluminum composite foams produced from powder compacts: foaming and compression behavior, Journal of Materials Science 41 (13) (2006) 4075-4084.

[22] ASTM, C240-97, in: Standard Test Methods of Testing Cellular Glass Insulation Block, ASTM International, West Conshohocken, PA, 2003.

[23] N.M. Bobkova, S.E. Barantseva, E.E. Trusova, Production of foam glass with granite siftings from the Mikashevichi deposit, Glass and Ceramics 64 (1-2) (2007) 47-50.

[24] D.U. Tulyaganov, H.R. Fernandes, S. Agathopoulos, J.M.F. Ferreira, Preparation and characterization of high compressive strength foams from sheet glass, Journal of Porous Materials 13 (2) (2006) 133-139.

[25] R.M. Silverstein, F.X. Webster, D.J. Kiemle, Spectrometric Identification of Organic Compounds, Hoboken, NJ, John Wiley \& Sons, 2005. 
[26] M. Dussauze, V. Rodriguez, A. Lipovskii, M. Petrov, C. Smith, K. Richardson, T. Cardinal, E. Fargin, E.I. Kamitsos, How does thermal poling affect the structure of soda-lime glass?, Journal of Physical Chemistry C 114 (29) (2010) 12754-12759.

[27] L.J. Gibson, M.F. Ashby, Cellular Solids, Second ed., Cambridge University Press, Cambridge, UK, 1999.

[28] A.I. Shutov, L.I. Yashurkaeva, S.V. Alekseev, T.V. Yashurkaev, Study of the structure of foam glass with different characteristics, Glass and Ceramics 64 (9-10) (2007) 297-299.

[29] O.V. Kaz'mina, V.I. Vereshchagin, A.N. Abiyaka, Prospects for use of finely disperse quartz sands in production of foam-glass crystalline materials, Glass and Ceramics 65 (9-10) (2008) 319-321.

[30] O.V. Kaz'mina, V.I. Vereshchagin, A.N. Abiyaka, Assessment of the compositions and components for obtaining foam-glass-crystalline materials from aluminosilicate initial materials, Glass and Ceramics 66 (3-4) (2009) 82-85.

[31] J. Garcia-Ten, A. Saburit, M.J. Orts, E. Bernardo, P. Colombo, Glass foams from oxidation/reduction reactions using $\mathrm{SiC}, \mathrm{Si}_{3} \mathrm{~N}_{4}$ and AlN powders, Glass Technology: European Journal of Glass Science and Technology Part A 52 (4) (2011) 103-110.

[32] A.S. Llaudis, M.J.O. Tari, F.J.G. Ten, E. Bernardo, P. Colombo, Foaming of flat glass cullet using $\mathrm{Si}_{3} \mathrm{~N}_{4}$ and $\mathrm{MnO}_{2}$ powders, Ceramics International 35 (5) (2009) 1953-1959.

[33] M.S. Garkavi, O.K. Mel'chaeva, A.I. Nazarova, Effect of the process parameters of mix preparation on the properties of foam glass, Glass and Ceramics 68 (1-2) (2011) 44-46. 